\title{
簡易ガス吸着法による金属粉末 の比表面積の測 定 ${ }^{*}$
}

高柳重敏**

Shigetoshi Takayanagi: A Simplified Procedure for Measuring the Surface Area of Metal Powders by Gas Adsorption. (Study of the Surface States of Tungsten Powder (1)). This article gives a description of a modification of the standard BrunanerEmmett-Teller (BET) method for the determination of the surface area of metal powders. The modified procedure involves the use of $\mathrm{CO}_{2}$ as adsorbate, the determination of adsorption isotherm from three measured points and other simplifications. The use of $\mathrm{CO}_{2}$ for tungsten and molybdenum powders seems to give just as satisfactory results as in the case of conventional $\mathrm{N}_{2}$. It is shown that values within $2 \%$ of those by the standard method using $\mathrm{CO}_{2}$ are obtained by this simplified procedure One sample can be measured in about $1.5 \mathrm{hr}$ with the result reproducible within $2 \%$.

(Received August 10, 1959)

\section{I. 緒}

言

タングステン $(\mathrm{W})$, モリブデン（Mo）を始め粉末治金

* タングステン粉末の表面状態の研究（第 1 報）

飞使用される金属粉末では，その化学的性質のほか飞粉末 粒子の大きさ拉よび分布, 粒子の形状. 集合状態などが粉 末治金の工程と重要な関係のある性質としてとり上げられ ている.そしてその測定と観察には見掛け比重の測定, 
空気透過法, 沈降法による測定, X線, 光学および電子顕 微鏡による観察などが用いられている。しかしこれらの測 定，観察法にはそれぞれ一長一短があつて. 金属粉末の研 究にはその目的の種類によつて適当な方法を選ぶ必要があ る(1)(2).

最近 BET ガス吸着法(3)(4)が粉末治金の領域でも盛んに 用いられるようになつた。しかしほとんどが粉末粒子の平 均の大きさの尺度をきめる測定方法として用いられている ようである。

$\mathrm{BET}$ 法では粉末などの固体表面へのガスの低温におけ 万物理吸着等温曲線から, その単分子吸着層量を求めるこ とこよりその比表面積の決定がなされる。したがつて, 理 論的には分子的大きさに近い表面の微小変化まで検知でき る特徵がある.それ故この方法を粉末粒子の表面の粗さや, 酸化，還元などの化学反応にともなら表面状態の変化の測 定に用いればもつと有用な知識が得られるであろう。しか し BET 法には测定操作が厄介で，かつ測定に時間がかか るという久点がある. 標準 BET 法では試料のガス出しに $6 \mathrm{hr}$ 以上, 実際の測定操作にも $6 \mathrm{hr}$ 以上もかかるので, 研究を進める上にブレーキとなることも俴 マ起るであろ 5.そのため BET 法についての最近の提案 (5) (6) は単純化 して時間を節䄪する方向にむけられてきた。その要点は次 の如くなる.

(a) 排気時間を短縮する.

(b) 単分子層形成に要する吸着量 $\boldsymbol{v}_{m}\left(\mathrm{~cm}^{3}\right)$ は BET 吸 着等温式

$$
P / v\left(P_{s}-P\right)=1 / v_{m} C-(C-1) / v_{m} C \times P / P_{s}
$$

$P_{s}(\mathrm{mmHg})$ : 吸着温度に扣けるガスの飽和蒸気圧

$P(\mathrm{mmHg})$ : 吸着平衡圧力

$v\left(\mathrm{~cm}^{3}\right)$ : 压力 $P$ で吸着されたガス量

$C$ : 吸着ガスの液化熱と気化熱に関係する常数

で $C \geqq 1$ であるから $C$ に対して 1 を無視すれば, $P / P s$ が $0.1 〜 0.3$ の範囲で 等温曲線の一点だけを測定し, それを 原点と結び $P / P s$ と $P / v(P s-P)$ の傾斜から求められる (1 点法).

（c）気相中に残るガスの容積 (死容積) は普通 He で実 測するが, 吸着容器の容積を予め測定しておき, 粉末の比 重はバルクの比重に等しいと仮定し計算で求める. このよ うにして 1 試料につき $1 \mathrm{hr}$ 内外の短時間で測定でき，し かも工業的に利用できる精度が得られている. Emmett(3)

(1) J.M.Dallavalle: Micromeritics 2nd Ed. Pitman Pub. N.Y (1948).

(2) Symposium on New Methods for Particle Size Determination in the Subsieve Range, ASTM, (1941).

(3) P.H.Emmett: Advance in Colloidal Science. vol. 1, chap. 1

（4）日本化学会編：実験化学講座, 第 7 表, (1956),48 (丸善).

(5) F.M.Starkweather and D.T.Palumbo: J.Electrochem. Soc., 104(1957),287.

(6) P.Hersch: J.Inst. Metals, 86(1958), 509. によれば（b）に基ずく誤差は標準值の $5 \%$ 以内である. また Bugge, Kerlogue(7) は（a）执よび(c)により標準 值の約 $3 \%$ の負誤差を生ずるといつている. したがつて, このような簡略化による最大誤差は標準法で求めた值のほ ほ $10 \%$ (負誤差) に達するといわれている. しかし上に 述べたような粉末粒子の微少变化を追跡するためには，む つと高い精度が必要であろ5。また単純化法に用いられる ガスは一般に $\mathrm{N}_{2}$ である.この場合には液体酸素の沸点 - $183^{\circ}$, または液体窒素の沸点 $-195^{\circ}$ の温度を使用し なければならないので,これらの液化ガスの入手し難い場 合，実験遂行が困難になるなどの欠点がある.

著者は上に述べた諸点を考虑して吸着ガスとして $\mathrm{CO}_{2}$ を使用し, 比較的簡易に得られるドライアイスーフルコー ル寒剤の温度, $-78^{\circ}$ で測定できるように標準法を簡略化 し，しかも精度の高い测定法を考案検討した。

$\mathrm{CO}_{2}$ についてはすでに Schellinger(8) が食塩, 石英を 始め Pyrite らの鉱物粉末の表面積测定に用いている. 彼 はこれらの粉末に対する $\mathrm{CO}_{2}$ の吸着が $\mathrm{BET}$ 式を満足す ることを認め， $\mathrm{N}_{2}$ と同じように使用でさると述べている. しかし他の吸着ガスとの実験的比較や，精度，再現性など についてはふれていない. 本報では金属粉末についてこれ らの点を検討するとともに，考案した簡易 BET 吸着法に よる比表面積测定法について述べる.

\section{II. 装置および測定方法}

\section{1. 標準 BET 吸着法}

簡易法と比較するなどの目的で用いた標準 BET 法の装 置は，普通に用いられる標準設計(3)のものである・測定操 作の概要を述べると：(1)試料を吸着容器に入れて装置に熔 封する. (2)試料に吸着している水分, ガスを除くためにま ず室温で $1 \mathrm{hr}$, 次いで試料を電気炉で $160^{\circ}$ に加熱しつつ水 銀拡散ポンプで $6 \mathrm{hr}$ 以上排気する. 最後の真空度は 10-4 〜10-5 mmHg (マクレオドゲージで) である. (3)排気終 了後 He を用いて死容積を测定する. (4)20〜210 m m Hg の平衡圧力の範囲で 5〜6 ケの吸着点を測定する. (5)吸着 等温曲線から 比表面積を算出する. (3)〜(4) の測定操作に 約 $4 \mathrm{hr}$ かかつた.

\section{2. 簡易 BET 測定法}

簡易法に使用した装置を Fig.1 に示す。ほとんど標準 法に準ずるが次の点を変えた。 (1)試料のとりかえを容易に するため, 吸着バルブは擦り合わせて装置につなぐ.(2)金 属粉末では小孔, 微小亀裂などが少く, 水銀の吸着の影響 はほとんどないと考えられるので, 吸着容器前の U 字ト ラップは除いた．また操作も簡略化したすすなわち（1)排 気は $160^{\circ}$ で $1 \mathrm{hr}$ 行了. (2)吸着容器, 毛細管などは予め 組立前水銀でその容積を測定しておき，死容積は $\mathrm{He}$ を使 用しないで計算で求める. (3)測定点を 3 点とし, 全测定を

(7) P.E.Bugge and R.H.Kerlogue: J.Soc. Chem. Ind. London, 66(1947), 379.

(8) A.K.Schellinger: Min. Eng., 4(1952), 369. 
$40 \min$ 以内で行 5 .

\section{III. 実験結果および考察}

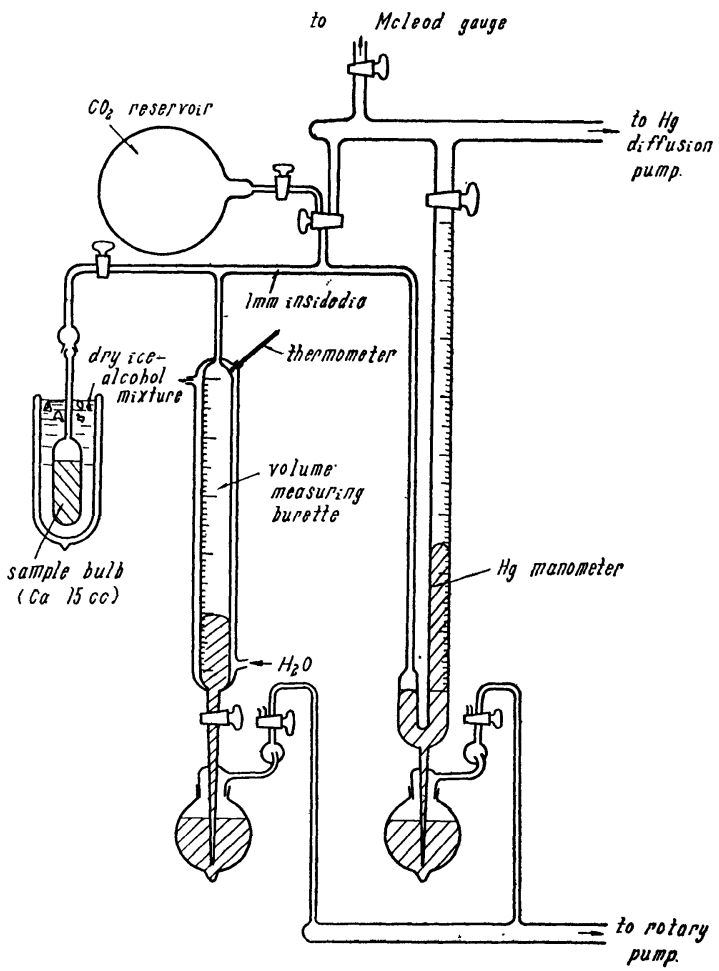

Fig. 1 Apparatus for the simplified B.E.T $\operatorname{method}\left(\mathrm{CO}_{2}\right)$.

1. 標準法によつて測定したW 粉末比表面 積のカススの種類による差異の検討

鉄触媒を始め各種鉣物粉末に対し, $\mathrm{CO}_{2}$ か $P / P_{s} ; 0.05$ 〜0.3 の压範囲で BET 式を満足する等温吸着 $\left(-78^{\circ}\right)$ をすることはよく知られている(3) (8). 著者は W, Mo など

$3 \mathrm{hr}$ 浸漬後, 純水洗滌, 真空乾燥して用いた

$\mathrm{A}: 5 \% \mathrm{HF}$ 溶液に浸漬処理したもの

$\mathrm{B}: 5 \% \mathrm{HCl}$ 溶液に浸漬処理したもの

$\mathrm{C}: 5 \% \mathrm{H}_{2} \mathrm{SO}_{4}$ 溶液に浸漬処理したもの

測定には粉末 $15 \sim 20 \mathrm{~g}$ を使い, $\mathrm{N}_{2}$ と A は $-183^{\circ}, \mathrm{CO}_{2}$ は $-78^{\circ}$ で吸着を行わせ $S$ を求めた。但し $S$ を算出す るに当つて吸着分子 1 ケ当りの占有面積は

$$
\begin{aligned}
& \mathrm{N}_{2}\left(-183^{\circ}\right) ; 17 \times 10^{-16} \mathrm{~cm}^{2} \\
& \mathrm{~A}\left(-183^{\circ}\right) ; 14.4 \times 10^{-16} \mathrm{~cm}^{2} \\
& \mathrm{CO}_{2}\left(-78^{\circ}\right) ; 17 \times 10^{-16} \mathrm{~cm}^{\dagger}
\end{aligned}
$$

の值を用いた・測定結果を Table 1 に示す.

Emmett, Brunauer らは $\mathrm{N}_{2}$ のほかに $\mathrm{A}, \mathrm{O}_{2}, \mathrm{CO}, \mathrm{CO}_{2}$, $\mathrm{C}_{4} \mathrm{H}_{10}$ などのガスを用いてアンモ二ヤ合成用鉄触媒, 熔銅 触媒, シリカゲルなどの $S$ を比較している. その結果に よれば $\mathrm{CO}, \mathrm{CO}_{2}$ で求めた值は $\mathrm{N}_{2}$ で求めた值に比較的よ く一致している.すなわち $\mathrm{N}_{2}\left(-183^{\circ}\right)$ で求めた $S$ に対 し $\mathrm{CO}_{2}\left(-78^{\circ}\right)$ で求めた $S$ は $0 \sim+6.5 \%$ であるのに比 ベ $\mathrm{A}\left(-183^{\circ}\right)$ で求めた $S$ は -4.9 〜 $-20.3 \%$ となつて いる. W 粉末についても 上表からわかるように, $\mathrm{CO}_{2}$ で 求めた $S$ は $\mathrm{N}_{2}$ で求めた $S$ に対し $-1 \sim+6 \%$ で上述 の結果とよく一致している.しかしアルカリ塩または硅酸 カリウムなどをドープした W 粉末のように粒子表面に $\mathrm{CO}_{2}$ を吸収する不純物が存在したり，また試料表面が化学 的な吸着ないし吸収を括こすような場合にはその量に対す る補正をしないと, 単分子層形成に要する吸着量 $\boldsymbol{v}_{m}$ にか なりの差異がでる．このようなときには物理吸着をおこな わせる前に一度 $\mathrm{CO}_{2}$ を導入し，試料表面に吸収ないし化 学吸着させて後一旦排気し，改めて吸着量を測定すればほ とんど妨害を与えない。このような注意をすれば $\mathrm{CO}_{2}$ ガ スは W などの金属粉末の比表面積測定に十分使用するこ with different adsorbates.

Table 1 Surface area obtained with different
(by the standard BET method)

\begin{tabular}{c|c|c|c|c|c|c|c|c|c}
\hline \multirow{2}{*}{ Sample } & \multicolumn{2}{|c|}{$\mathrm{N}_{2}\left(-183^{\circ}\right)$} & \multicolumn{2}{c|}{$\mathrm{A}\left(-183^{\circ}\right)$} & \multicolumn{3}{c}{$\mathrm{CO}_{2}\left(-78^{\circ}\right)$} \\
& $\begin{array}{c}\boldsymbol{v}_{m} \\
(\mathrm{cc} / \mathrm{g})\end{array}$ & $\begin{array}{c}\boldsymbol{S}_{\mathrm{N} 2} \\
\left(\mathrm{~cm}^{2} / \mathrm{g}\right)\end{array}$ & $\begin{array}{c}\boldsymbol{a}_{m} \\
(\mathrm{cc} / \mathrm{g})\end{array}$ & $\begin{array}{c}S_{\mathrm{A}} \\
\left(\mathrm{cm}^{2} / \mathrm{g}\right)\end{array}$ & $\frac{S_{\mathrm{A}}-S_{\mathrm{N}_{2}} \times 100}{S_{\mathrm{N}_{2}}}$ & $\begin{array}{c}\boldsymbol{v}_{m} \\
(\mathrm{cc} / \mathrm{g})\end{array}$ & $\begin{array}{c}S_{\mathrm{CO} 2} \\
(\mathrm{~cm} 2 / \mathrm{g})\end{array}$ & $\frac{S_{\mathrm{CO} 2}-S_{\mathrm{N} 2} \times 100}{S_{\mathrm{N}_{2}}}$ \\
\hline $\mathrm{A}$ & 0.0430 & 1,980 & 0.0440 & 1,715 & -8.9 & 0.0426 & 1,960 & -1.02 \\
$\mathrm{~B}$ & 0.1880 & 8,640 & 0.2075 & 8,080 & -6.7 & 0.2000 & 9,200 & +6.26 \\
$\mathrm{C}$ & 0.2306 & 10,640 & 0.2618 & 10,200 & -4.2 & 0.2315 & 10,720 & +0.75 \\
\hline
\end{tabular}

の金属粉末に対する $\mathrm{CO}_{2}$ の等温吸着の結果も $\mathrm{BET}$ 式に 適合することを確認した. 次にこのような金属粉末の表面 積決定に吸着ガスとして $\mathrm{CO}_{2}$ を用いることの適否を調べ るために, ガスの種類による比表面積值 $S$ の差異を検討 した.それには標準法で $\mathrm{N}_{2}, \mathrm{~A}$ 扣よび $\mathrm{CO}_{2}$ を用いた場 合の $S$ を比較した。実験に用いた $\mathrm{He}, \mathrm{A}$ および $\mathrm{N}_{2}$ は 帝国酸素より購入した純度 $99.9 \%$ 以上のもので, $\mathrm{CO}_{2}$ は特級の $\mathrm{NaHCO}_{3}$ 粉末を真空中で加熱分解し, 塩化 カルシウム, 五酸化燐で脱水して用いた.W粉末試料は普 通工業的に行われるように連続炉で水素還元したもので， 各種の S を得るために同じ粉末を次のように 3 種の液に
とができ，臣とんど補正しないでも従来の $\mathrm{N}_{2}\left(-183^{\circ}\right)$ を 用いた值と比較できるであろう。

\section{2. 簡易法 $\left(\mathrm{CO}_{2}\right.$ ガス吸着法)による測定結果}

\section{（1）標準法との比較}

1 と同じ粉末試料 15〜20 g を用いて簡易法で測定した $\mathrm{S}$ と, $\mathrm{CO}_{2}$ ガスを用い標準法で求めた $\mathrm{S}$ との比較を $\mathbf{T a}$ -

$\dagger \mathrm{CO}_{2}$ の分子占有断面積は $-78^{\circ}$ では固体状態の面積 $14.1 \times 10^{-18} \mathrm{~cm}^{2}$ が適当であるとしているが, Emmett らの各種ガス比較結果を参照し, $\mathrm{N}_{2}\left(-183^{\circ}\right)$ で 測定した比表面積值と比較ずるためには, 液体状態の 面積 $17 \times 10^{-16} \mathrm{~cm}^{2}$ を用いた方がよく一致するので 便宜上この値を用いた。 
ble 2 に示す.

Starkweather, Palumbo(5) は $\mathrm{N}_{2}$ ガス吸着による標

Table 2 Surface areas obtained by the standard and the simplified BET method.

\begin{tabular}{c|r|r|r}
\hline \hline Sample & $\begin{array}{r}\text { Standard } \\
\left(\mathrm{cm}^{3} / \mathrm{g}\right)\end{array}$ & $\begin{array}{c}\text { Simplified } \\
\left(\mathrm{cm}^{2} / \mathrm{g}\right)\end{array}$ & $\begin{array}{c}\text { Dev. \% of Standard } \\
\text { value }\end{array}$ \\
\hline A & 1,960 & 1,950 & -0.51 \\
B & 9,200 & 9,100 & -1.09 \\
C & 10,700 & 10,500 & -1.87 \\
\hline
\end{tabular}

準法と， 1 点法という極めて簡略化した簡易法を比較して いる. 彼らによれば簡易法で求めた各種粉末の比表面積值 は標準法より常に小さくー4〜ー10\%の相違がある.そし てこの䛊差の原因は 1 点法を用いることと, 試料の排気の 不完全さにあるといつている. しかし 1 点法の代りに著者 の用いた 3 点法にすれば吸着等温曲線の傾斜がもつと精度 よく求められるので誤差は少くなるであろう．Table 3 は 同じ試料について同一装置で $\mathrm{CO}_{2}$ を用い 1 点法と 3 点法

Table 3 Surface areas obtained by the 1-point and the 3-points method.

\begin{tabular}{c|r|r|c}
\hline \hline Sample & $\begin{array}{c}\text { 3-points } \\
\text { method } \\
\left(\mathrm{cm}^{2} / \mathrm{g}\right)\end{array}$ & $\begin{array}{c}\text { 1-point } \\
\text { method } \\
\left(\mathrm{cm}^{2} / \mathrm{g}\right)\end{array}$ & $\begin{array}{c}\text { Dev.\% of the value } \\
\text { of 3-points method }\end{array}$ \\
\hline A & 1,950 & 1,830 & -6.0 \\
B & 9,100 & 8,750 & -3.8 \\
C & 10,500 & 10,000 & -4.8 \\
$\# 11$ & 19,500 & 18,200 & -6.7 \\
$\# 21$ & 23,600 & 22,100 & -6.3 \\
\hline
\end{tabular}

で測定した S の比較を示す.な拐別の W 粉末の結果も 併記した. ただし 1 点法は圧力 $140 \mathrm{~mm} \mathrm{Hg}$ で測定した.

Table 2 および Table 3 から 3 点法の方が標準法の $S$ に近い値が得られることがわかる. また 3 点法を用いて も最初の吸着点のほかは 1 点当りの吸着時間は 5 〜 $10 \mathrm{~min}$ で十分であつた. したがつて時間的にも 1 点法に比べて 15〜25 min 長くなるにすぎない. な敃簡易法で W 粉末の $\mathrm{S}$ を測定した実験に拈いて, 排気条件の差が測定結果にお よぼす影響を検討した結果,温度 $140 〜 160^{\circ}$ では排気時間 1 〜7hr の間で測定値の相違は認められなかつた(Table 4).

Table 4 Effect of outgassing schedule on $v_{m}$.

\begin{tabular}{c|c|c|cc}
\hline $\begin{array}{c}\text { Temp. } \\
\left({ }^{\circ} \mathrm{C}\right)\end{array}$ & $\begin{array}{c}\text { Time } \\
\text { (hr) }\end{array}$ & $\begin{array}{c}\boldsymbol{v}_{m} \\
(\mathrm{cc} / \mathrm{g})\end{array}$ & $\begin{array}{l}\text { Error, \% } \\
\text { dard value }\end{array}$ & of \\
\hline 0 & 2 & 2.28 & -2.6 \\
120 & 2 & 2.28 & -2.6 \\
160 & $1 / 6$ & 2.28 & -2.6 \\
160 & 2 & 2.34 & 0 \\
700 & 2 & 2.30 & -1.7 \\
$160 *$ & 7 & 2.34 & $*$ \\
\hline
\end{tabular}

* Standard outgassing schedule

これは $\mathrm{W}$ 粉末のように粒子の形が比較的簡単で小孔も少 い金属粉末では, 比表面積もそれ程大きくないので排気が 容易に行われるためであろう.

Table 5,6,7 は簡易法の再現性を示すデーターである.
同一試料を装置から取りはずすことなく5 回繰り返し.测定 したときの平均偏差は 1.1 および $1.4 \%$ であつた. 2 回 繰り返し測定したときの平均偏差は Table 6,7 に示すよ ラに同一試料では 0 〜 $0.5 \%$, 同じ粉末からとつた 2 試料 では 0〜 $1.5 \%$ であつた。これらの偏差は標準法のそれと ほとんど変らなかつた. したがつて排気, 加熱, その他取

Table 5 Reproducibility of the simplified BET determinations.

(same samples re-run without being removed from the apparatus)

\begin{tabular}{c|c}
\hline$\# 1$ & \# 2 \\
\hline 4,700 & 1,900 \\
4,720 & 1,930 \\
4,720 & 1,930 \\
4,810 & 1,930 \\
4,810 & 1,950 \\
\hline $4,752 \pm 67$ & $1,928 \pm 22$ \\
\hline
\end{tabular}

Table 6 Reproducibility of the simplified BET determinations.

(Same samples used for runs 1 and 2)

\begin{tabular}{c|c|c}
\hline \hline Sample & $\begin{array}{c}S \\
\left(\mathrm{~cm}^{2} / \mathrm{g}\right)\end{array}$ & $\begin{array}{c}\text { avg. dev. } \\
(\%)\end{array}$ \\
\hline$\# 3$ & 2,050 & 0.25 \\
2,040 & 0 \\
\hline 4 & 5,670 & 0 \\
\hline$\# 8$ & 5,670 & 0.40 \\
\hline$\# 9$ & 5,820 & 0.50 \\
\hline
\end{tabular}

Table 7 Reproducibility of the simplified BET determinations.

(Different samples of same powders used for runs 1 and 2)

\begin{tabular}{c|c|c}
\hline Sample & $\begin{array}{c}S \\
\left(\mathrm{~cm}^{2} / \mathrm{g}\right)\end{array}$ & $\begin{array}{c}\text { avg. dev. } \\
(\%)\end{array}$ \\
\hline$\# 5$ & 2,340 & 0 \\
\hline$\# 6$ & 2,340 & 0.42 \\
\hline$\# 7$ & 2,370 & 0.86 \\
\hline$\# 12$ & 3,550 & 1.48 \\
\hline
\end{tabular}

扱い中の試料の変化に注意すれば再現性もすぐれていると いえる. 以上の結果を総括すると, この簡易法で測定した $\mathrm{W}$ 粉末の $\mathrm{S}$ の平均偏差は $2 \%$ 以内で, $\mathrm{CO}_{2}$ ガスを用い 標準法で求めた $\mathrm{S}$ に対し $-2 \%$ 以内で一致させること ができる、また $\mathrm{CO}_{2}$ で求めた $\mathrm{S}$ は従来いわれているよ5

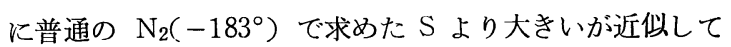
いるので, 従来のデーターと比較するのに 好都合であろ 5 .

その後水索還元法で作つた $\mathrm{Mo}, \mathrm{Ni}$, カーボニール Ni 
などの金属粉末の $S\left(1,000 \sim 10,000 \mathrm{~cm}^{2} / \mathrm{g}\right)$ の測定にこの 簡易法を適用して，いずれも満足すべさ結果を得た。

\section{IV. 結 言}

$\mathrm{W}$ 粉末の比表面積を短時間に, しかも精度, 再現性を 損うことなく測定できる簡易 BET 法について検討した.

$\mathrm{CO}_{2}$ ガスを用いる 3 点法は测定操作が簡単で, 1 点法と あまり変らない時間で測定でき, しかも精度がすぐれてい
ることを明らかにした。この簡易法を用いて水素還元で作 つた直後の W 粉末粒子の比表面積や, 洗滌処理, 酸化, 還元にともなら比表面積变化の様子を調べた結果, 種々の 新しい知識が得られた. それらについては次報で 報告す る.

本研究を行うに当つて終始懇切なる御指導を賜つた京都 大学佐々木教授に対し深く感謝の意を表します。また発表 を許可された松下電子工.業株式会社执よび実験に協力され た沢田良治氏に厚く和礼申し上げます. 